\title{
Synthesis, Spectroscopic Characterization, DFT Calculations and Preliminary Antifungal Activity of New Piperine Derivatives
}

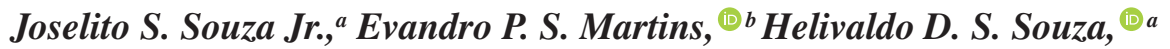 \\ Rafael F. de Oliveira, ${ }^{\oplus a}$ Francinara S. Alves, ${ }^{a}$ Edeltrudes O. Lima, ${ }^{c}$ Laísa V. Cordeiro, ${ }^{c}$ \\ Emmely O. Trindade, ${ }^{a}$ Bruno F. Lira, ${ }^{a}$ Gerd B. Rocha, ${ }^{a}$ Petronio F. de Athayde-Filho ${ }^{a}$ \\ and José M. Barbosa-Filho ${ }^{\circledR *, c}$ \\ ${ }^{a}$ Departamento de Química, Universidade Federal da Paraíba, 58051-900 João Pessoa-PB, Brazil \\ ${ }^{b}$ Departamento de Química, Universidade Estadual do Piauí, 64260-000 Piripiri-PI, Brazil \\ ${ }^{c}$ Departamento de Ciências Farmacêuticas, Universidade Federal da Paraíba, \\ 58051-900 João Pessoa-PB, Brazil
}

\begin{abstract}
Four new piperine derivatives, PC1-PC4, were synthesized, and their structures were fully characterized by infrared (IR) and ${ }^{1} \mathrm{H}$ and ${ }^{13} \mathrm{C}$ nuclear magnetic resonance (NMR) spectroscopies. Quantum chemical calculations were performed using density functional theory (DFT) with the B3LYP-D3/6-31G(d,p) and 6-311+G(2d,p) basis sets. Electronic properties, such as the energy gap between the highest occupied molecular orbital (HOMO) and the lowest unoccupied molecular orbital (LUMO) and some global chemical reactivity descriptors, were evaluated to study the reactivity and stability of the compounds. ${ }^{1} \mathrm{H}$ and ${ }^{13} \mathrm{C}$ NMR chemical shifts were calculated by using the gauge-invariant atomic orbital (GIAO) method and compared with experimental values. In addition, the compounds were evaluated in an antifungal study against Candida, Trichophyton and Microsporum strains, and only PC4 showed 70\% inhibition in ten tested strains, with a minimum

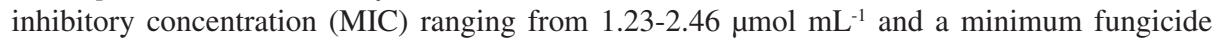
concentration (MFC) ranging from 9.84-19.68 $\mu \mathrm{mol} \mathrm{mL}^{-1}$, and presented a fungistatic effect.
\end{abstract}

Keywords: piperine, synthesis, NMR, DFT, antifungal activity

\section{Introduction}

The rates of fungal resistance to drugs highlight an increasingly serious health problem and make it necessary to develop new therapeutic alternatives to treat these infections, since the options available today are mainly limited to azoles and echinocandins. More than one billion individuals worldwide are affected by fungal infections, and the associated mortality is over 1.5 million deaths each year. In this context, traditional medicine can serve as a guide during the process of discovering antifungal drugs, using the knowledge of plants used historically as anti-infectious agents. ${ }^{1,2}$

Plants, which are a major source of traditional medicines, are also promising sources for new drugs due to the presence of secondary metabolites with a wide range of biological activity, such as antimicrobial activity. In

*e-mail: jbarbosa@ltf.ufpb.br many cases, these substances play a role in plant defense mechanisms against predation by microorganisms, insects, and herbivores. Some plants used for their odor (terpenoids), pigment (quinones and tannins), and flavor (terpenoid capsaicin from chili peppers) have been found to also possess medicinal properties. There is an enormous chemical diversity of natural products from plants, and these products can be used directly or used as a precursor for developing better molecules. ${ }^{3,4}$

Piperine $\left(\mathrm{C}_{17} \mathrm{H}_{19} \mathrm{NO}_{3}\right)$ is a naturally occurring alkaloid and is one of the main secondary metabolites found in Piper nigrum and P. longum. ${ }^{5}$ However, piperine can also be found in other species of the genus Piper, such as $P$. guineense, ${ }^{6}$ P. interruptum, ${ }^{7}$ P. sarmentosum ${ }^{8}$ and $P$. chaba. ${ }^{9}$ Amide alkaloids have pharmacological efficacies, such as antifungal, ${ }^{10}$ antibacterial, ${ }^{11}$ analgesic, ${ }^{12}$ antipyretic, ${ }^{12}$ anti-inflammatory, ${ }^{12}$ antileishmanial, ${ }^{13}$ and larvicidal ${ }^{14}$ activities. Piperine can be isolated by various methods, such as maceration using acetic acid, extraction 
with ethanol in a Soxhlet apparatus, microwave-assisted extraction, and extraction using ultrasound. ${ }^{15}$ Piperine derivatives represent a wide range of important biological properties, such as antifungal (1), ${ }^{16}$ larvicidal (2), ${ }^{17}$ trypanocidal (3), ${ }^{18}$ antidiabetic (4), ${ }^{19}$ and antitumor $(\mathbf{5})^{20}$ activities (Figure 1).

Thus, taking into account the potential of piperine in the development of drug candidates, four new compounds were synthesized and characterized by infrared (IR) and ${ }^{1} \mathrm{H}$ and ${ }^{13} \mathrm{C}$ nuclear magnetic resonance (NMR) spectroscopy. In addition, the conformational, electronic and NMR spectroscopic properties of the compounds were calculated by using density functional theory (DFT). Using this method, the quantum chemical parameters, such as hardness $(\eta)$, chemical potential $(\mu)$ and electrophilic index $(\omega)$, were calculated to characterize the global chemical reactivity of these compounds. The ${ }^{1} \mathrm{H}$ and ${ }^{13} \mathrm{C}$ NMR chemical shifts were calculated and used to evaluate the correlation between the theoretical and experimental data. Furthermore, a preliminary study of the antifungal activity of the compounds against 10 species of fungi (7 yeasts and 3 filamentous) was included.

\section{Experimental}

Chemistry

All reagents and solvents used were purchased from commercial sources (Sigma-Aldrich $^{\circledR}$, São Paulo, Brazil) and used without further purification. The purification of the compounds was performed by recrystallization in a mixture of $\mathrm{N}, \mathrm{N}$-dimethylformamide (DMF)/water and confirmed by determining the melting range on an MQAPF-302 hotplate (Microquímica). ${ }^{1} \mathrm{H}$ and ${ }^{13} \mathrm{C}$ nuclear magnetic resonance (NMR) spectra were obtained on two different machines: a Bruker Avance Ultrashield TM ( $400 \mathrm{MHz}$ for ${ }^{1} \mathrm{H}$ and $101 \mathrm{MHz}$ for ${ }^{13} \mathrm{C}$ ) and a Bruker Avance Ultrashield $\mathrm{TM}\left(500 \mathrm{MHz}\right.$ for ${ }^{1} \mathrm{H}$ and $126 \mathrm{MHz}$ for $\left.{ }^{13} \mathrm{C}\right)$. Deuterated chloroform $\left(\mathrm{CDCl}_{3}\right)$ and deuterated dimethyl sulfoxide (DMSO- $d_{6}$ ) were used as solvents, and tetramethylsilane (TMS) was used as the internal standard. Chemical shifts $(\delta)$ were measured in parts per million ( $\mathrm{ppm})$, and the coupling constants $(J)$ were measured in hertz $(\mathrm{Hz})$. Infrared (IR) spectra were obtained on a Shimadzu model IR Prestige-21 FTIR spectrometer with an attenuated total reflection (ATR) accessory.

\section{Piperine extraction $(6)^{5}$}

Two hundred grams of black pepper was ground to a fine powder and extracted with $1000 \mathrm{~mL}$ of $95 \%$ ethanol in a Soxhlet extractor for $2 \mathrm{~h}$. The solution was filtered and concentrated under vacuum. Then, $200 \mathrm{~mL}$ of a $10 \%$ alcoholic $\mathrm{KOH}$ solution was added to the residue, and the precipitated material was filtered. A small amount of water was added to the alcoholic solution, sufficient for the medium to become cloudy. The alcoholic solution was left overnight, and the precipitate was obtained as yellow needles. The obtained solid was washed with a small amount of ice water, and $7.0 \mathrm{~g}$ of piperine was obtained. mp 126-128 ${ }^{\circ} \mathrm{C}$ (lit.: $\left.{ }^{21} 125-126{ }^{\circ} \mathrm{C}\right) ;{ }^{1} \mathrm{H}$ NMR (500 MHz,<smiles>COC(=O)c1ccccc1OC(=O)/C=C/C=C/c1ccc2c(c1)OCO2</smiles>

(1)<smiles>O=C(/C=C/C=C/c1ccc2c(c1)OCO2)N/N=C/c1ccccc1</smiles>

(2)<smiles>O=C(/C=C/C=C/c1ccc2c(c1)OCO2)OCCCCOC(=O)c1ccc([N+](=O)[O-])cc1</smiles>

(5)

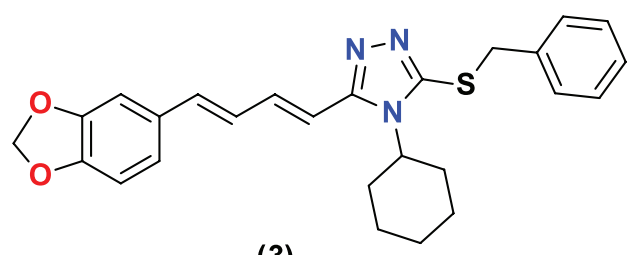

(3)<smiles>O=C(/C=C/C=C/c1ccc2c(c1)OCO2)Nc1nc2c(Cl)cccc2s1</smiles>

(4)

Figure 1. Piperine derivatives have antifungal (1), larvicidal (2), trypanocidal (3), antidiabetic (4) and antitumor (5) activities. 
$\left.\mathrm{CDCl}_{3}\right) \delta 7.38(\mathrm{ddd}, J 14.7,8.7,1.5 \mathrm{~Hz}, 1 \mathrm{H},=\mathrm{C}-\mathrm{H}), 6.96$ $\left(\mathrm{d}, J 1.6 \mathrm{~Hz}, 1 \mathrm{H}, \mathrm{C}-\mathrm{H}_{\mathrm{Ar}}\right), 6.87(\mathrm{dd}, J 8.0,1.7 \mathrm{~Hz}, 1 \mathrm{H}$, $\left.\mathrm{C}-\mathrm{H}_{\mathrm{Ar}}\right), 6.72\left(\mathrm{~m}, 3 \mathrm{H},=\mathrm{C}-\mathrm{H}\right.$ and $\left.\mathrm{C}-\mathrm{H}_{\mathrm{Ar}}\right), 6.42(\mathrm{~d}, J 14.7 \mathrm{~Hz}$, $1 \mathrm{H},=\mathrm{C}-\mathrm{H}), 5.95\left(\mathrm{~s}, 2 \mathrm{H}, \mathrm{OCH}_{2} \mathrm{O}\right), 3.57(\mathrm{~d}, J 52.5 \mathrm{~Hz}, 4 \mathrm{H}$, $\left.\mathrm{CH}_{2}\right), 1.65\left(\mathrm{~m}, 2 \mathrm{H}, \mathrm{CH}_{2}\right), 1.57$ (dt, J11.2, $5.6 \mathrm{~Hz}, 4 \mathrm{H}, \mathrm{CH}_{2}$ ); ${ }^{13} \mathrm{C}$ NMR $\left(126 \mathrm{MHz}, \mathrm{CDCl}_{3}\right) \delta 165.53,148.30,148.21$, $142.55,138.29,131.14,125.48,122.57,120.19$, 108.58, $105.79,101.37,24.77$.

\section{Potassium piperate (7)}

In a $100 \mathrm{~mL}$ flask, $6.0 \mathrm{~g}(0.021 \mathrm{~mol})$ of piperine was suspended in $60 \mathrm{~mL}$ of $20 \% \mathrm{KOH}$ alcoholic solution. The reaction mixture was kept under reflux and stirring for $20 \mathrm{~h}$. After completion of the reaction, the mixture was filtered, washed with ethanol, and dried, and $5.0 \mathrm{~g}$ (92.9\%) of a brown granular solid was obtained. ${ }^{1} \mathrm{H}$ NMR (400 MHz, $\left.\mathrm{D}_{2} \mathrm{O}\right) \delta 7.05(\mathrm{dd}, J 15.5,9.6 \mathrm{~Hz}, 1 \mathrm{H},=\mathrm{C}-\mathrm{H}), 6.86(\mathrm{~d}$, $\left.J 1.6 \mathrm{~Hz}, 1 \mathrm{H}, \mathrm{C}-\mathrm{H}_{\mathrm{Ar}}\right), 6.82\left(\mathrm{dd}, J 8.2,1.6 \mathrm{~Hz}, 1 \mathrm{H}, \mathrm{C}-\mathrm{H}_{\mathrm{Ar}}\right)$, $6.73\left(\mathrm{~d}, J 8.0 \mathrm{~Hz}, 1 \mathrm{H}, \mathrm{C}-\mathrm{H}_{\mathrm{Ar}}\right), 6.60(\mathrm{~m}, 2 \mathrm{H},=\mathrm{C}-\mathrm{H}), 5.92$ (d, J $15.2 \mathrm{~Hz}, 1 \mathrm{H},=\mathrm{C}-\mathrm{H}), 5.88\left(\mathrm{~s}, 2 \mathrm{H}, \mathrm{O}-\mathrm{CH}_{2}-\mathrm{O}\right)$.

\section{General preparation of arylacyl bromide $(\mathbf{9 a}-\mathbf{9 d})^{22}$}

In a $100 \mathrm{~mL}$ flask, a solution of bromine $(0.018 \mathrm{~mol})$ in chloroform $(5 \mathrm{~mL})$ was added dropwise to substituted aromatic ketones $(0.016 \mathrm{~mol})$ in chloroform $(50 \mathrm{~mL})$ at $0{ }^{\circ} \mathrm{C}$. The reaction mixture was stirred for an additional $24 \mathrm{~h}$ at room temperature. After the end of the reaction, the reaction mixture was subjected to extraction, washed with a saturated solution of $\mathrm{NaHCO}_{3}(3 \times 100 \mathrm{~mL})$ and a saturated solution of $\mathrm{NaCl}(2 \times 50 \mathrm{~mL})$ and dried over anhydrous sodium sulfate. The organic phase was filtered and concentrated under reduced pressure. The formed solid was used in the next step without further purification.

\section{General preparation of piperine derivatives (PC1-PC4)}

In a $50 \mathrm{~mL}$ flask, $10 \mathrm{~mL}$ of DMF was added to a mixture of $0.004 \mathrm{~mol}$ of potassium piperate and $0.004 \mathrm{~mol}$ of arylacyl bromide. The reaction mixture was stirred at a temperature of $100{ }^{\circ} \mathrm{C}$ for $24 \mathrm{~h}$. After the end of the reaction, the mixture was cooled, ice water was added, and the solid formed was separated by vacuum filtration and washed with distilled water. The crude product was recrystallized from a DMF/water (8:2) mixture.

\section{2-Oxo-2-phenylethyl-piperate (PC1)}

Yield: 60\%; pale yellow solid; mp 167-169 ${ }^{\circ} \mathrm{C}$; IR (ATR) v / cm $3062\left(\mathrm{C}-\mathrm{H}_{\text {Alke }}\right), 3037,3014\left(\mathrm{C}-\mathrm{H}_{\mathrm{Ar}}\right), 2933$, $2906(\mathrm{C}-\mathrm{H}), 1714$ ( $\mathrm{C}=\mathrm{O}$, ester), 1689 ( $\mathrm{C}=\mathrm{O}$, ketone), $1620\left(\mathrm{C}=\mathrm{C}_{\text {Alke }}\right), 1608$ and $1490\left(\mathrm{C}=\mathrm{C}_{\mathrm{Ar}}\right), 1448\left(\mathrm{CH}_{2}\right)$,
1257 and $1143\left(\mathrm{O}-\mathrm{CH}_{2}-\mathrm{O}\right), 927,852,752\left(\mathrm{C}-\mathrm{H}_{\mathrm{Ar}}\right)$; ${ }^{1} \mathrm{H}$ NMR $\left(500 \mathrm{MHz}, \mathrm{CDCl}_{3}\right) \delta 7.94(\mathrm{~d}, J 7.7 \mathrm{~Hz}, 2 \mathrm{H}, \mathrm{H}-16$ and H-16'), 7.61 (t, $J 7.4 \mathrm{~Hz}, 1 \mathrm{H}, \mathrm{H}-18), 7.51$ (dt, $J$ 15.0, $9.3 \mathrm{~Hz}, 3 \mathrm{H}, \mathrm{H}-3, \mathrm{H}-17$ and H-17'), 7.00 (s, 1H, H-7), 6.92 (d, J 7.9 Hz, 1H, H-10), 6.78 (ddd, J 26.3, 22.5, 13.2 Hz, $3 \mathrm{H}, \mathrm{H}-4, \mathrm{H}-5$ and H-11), 6.10 (d, J $15.2 \mathrm{~Hz}, 1 \mathrm{H}, \mathrm{H}-2), 5.98$ (s, 2H, H-12), 5.42 (s, 2H, H-13); ${ }^{13} \mathrm{C} \mathrm{NMR} \mathrm{(126} \mathrm{MHz,}$ $\left.\mathrm{CDCl}_{3}\right) \delta 166.38$ (C-1), 119.06 (C-2), 146.94 (C-3), 124.45 (C-4), 140.93 (C-5), 130.50 (C-6), 105.98 (C-7), 148.32 (C-8), 148.70 (C-9), 108.55 (C-10), 123.12 (C-11), 101.42 (C-12), 65.97 (C-13), 192.43 (C-14), 134.40 (C-15), 128.84 (C-16 and C-16'), 127.82 (C-17 and C-17'), 133.80 (C-18).

\section{2-(4-Nitrophenyl)-2-oxoethyl-piperate (PC2)}

Yield: 50\%; orange solid; mp 209-211 ${ }^{\circ} \mathrm{C}$; IR (ATR) $v / \mathrm{cm}^{-1} 3105\left(\mathrm{C}-\mathrm{H}_{\text {Alke }}\right), 3070\left(\mathrm{C}-\mathrm{H}_{\mathrm{Ar}}\right), 2910(\mathrm{C}-\mathrm{H}), 1716$ $(\mathrm{C}=\mathrm{O}$, ester $), 1703(\mathrm{C}=\mathrm{O}$, ketone $), 1620\left(\mathrm{C}=\mathrm{C}_{\text {Alke }}\right), 1606$, $1483\left(\mathrm{C}=\mathrm{C}_{\mathrm{Ar}}\right), 1523$ and $1346\left(\mathrm{NO}_{2}\right), 1444\left(\mathrm{CH}_{2}\right), 1249$ and $1139\left(\mathrm{O}-\mathrm{CH}_{2}-\mathrm{O}\right), 875,858,844\left(\mathrm{C}-\mathrm{H}_{\mathrm{Ar}}\right) ;{ }^{1} \mathrm{H}$ NMR $\left(500 \mathrm{MHz}, \mathrm{DMSO}-d_{6}\right) \delta 8.35(\mathrm{~d}, J 8.8 \mathrm{~Hz}, 2 \mathrm{H}, \mathrm{H}-17$ and H-17'), 8.20 (d, J 8.8 Hz, 2H, H-16 and H-16'), 7.46 (dd, $J 15.3,9.9 \mathrm{~Hz}, 1 \mathrm{H}, \mathrm{H}-3), 7.20$ (d, J $1.6 \mathrm{~Hz}, 1 \mathrm{H}, \mathrm{H}-7), 7.03$ $(\mathrm{m}, 2 \mathrm{H}, 3 \mathrm{H}, \mathrm{H}-4, \mathrm{H}-5$ and H-11), $6.91(\mathrm{~d}, J 8.0 \mathrm{~Hz}, 1 \mathrm{H}$, H-10), 6.14 (d, J 15.2 Hz, 1H, H-2), 6.04 (s, 2H, H-12), 5.56 (s, 2H, H-13); ${ }^{13} \mathrm{C} \mathrm{NMR}\left(126 \mathrm{MHz}, \mathrm{CDCl}_{3}\right) \delta 165.31$ (C-1), 118.52 (C-2), 145.87 (C-3), 124.37 (C-4), 140.78 (C-5), 130.18 (C-6), 105.73 (C-7), 147.78 (C-8), 148.11 (C-9), 108.24 (C-10), 122.89 (C-11), 101.11 (C-12), 66.27 (C-13), 192.37 (C-14), 138.64 (C-15), 129.00 (C-16 and C-16'), 123.59 (C-17 and C-17'), 150.16 (C-18).

\section{2-Oxo-2-( $p$-tolyl)ethyl-piperate (PC3)}

Yield: 65\%; orange solid; mp 187-189 ${ }^{\circ} \mathrm{C}$; IR (ATR) $\mathrm{v} / \mathrm{cm}^{-1} 3039\left(\mathrm{C}-\mathrm{H}_{\text {Alke }}\right), 3000\left(\mathrm{C}-\mathrm{H}_{\mathrm{Ar}}\right), 2924(\mathrm{C}-\mathrm{H}), 1712$ $(\mathrm{C}=\mathrm{O}$, ester $), 1695(\mathrm{C}=\mathrm{O}$, ketone $), 1608\left(\mathrm{C}=\mathrm{C}_{\text {Alke }}\right), 1602$ and $1485\left(\mathrm{C}=\mathrm{C}_{\mathrm{Ar}}\right), 1438\left(\mathrm{CH}_{2}\right), 1226$ and $1128\left(\mathrm{O}-\mathrm{CH}_{2}-\mathrm{O}\right)$, 925, 864, $819\left(\mathrm{C}-\mathrm{H}_{\mathrm{Ar}}\right) ;{ }^{1} \mathrm{H}$ NMR (400 MHz, DMSO- $\left.d_{6}\right)$ $\delta 7.86$ (d, J 8.0 Hz, 2H, H-17 and H-17'), 7.45 (dd, J 15.3, $9.3 \mathrm{~Hz}, 1 \mathrm{H}, \mathrm{H}-3$ ), 7.38 (d, J 8.0 Hz, 2H, H-16 and H-16'), 7.20 (s, 1H, H-7), 7.03 (t, J $11.0 \mathrm{~Hz}, 3 \mathrm{H}, \mathrm{H}-4, \mathrm{H}-5$ and H-11), 6.91 (d, J $8.0 \mathrm{~Hz}, 1 \mathrm{H}, \mathrm{H}-10), 6.14$ (d, J $15.2 \mathrm{~Hz}$, 1H, H-2), 6.04 (s, 2H, H-12), 5.47 (s, 2H, H-13), 2.40 (s, $\left.3 \mathrm{H}, \mathrm{CH}_{3}\right) ;{ }^{13} \mathrm{C}$ NMR (101 MHz, DMSO- $\left.d_{6}\right) \delta 165.37(\mathrm{C}-1)$, 118.87 (C-2), 145.55 (C-3), 124.42 (C-4), 140.56 (C-5), 130.22 (C-6), 105.72 (C-7), 147.78 (C-8), 148.07 (C-9), 108.23 (C-10), 122.85 (C-11), 101.10 (C-12), 65.88 (C-13), 192.19 (C-14), 131.52 (C-15), 127.51 (C-16 and C-16'), 129.12 (C-17 and C-17'), 144.03 (C-18), $20.87\left(\mathrm{CH}_{3}\right)$.

\section{2-(4-Bromophenyl)-2-oxoethyl-piperate (PC4)}

Yield: 58\%; pale yellow solid; mp 213-214 ${ }^{\circ} \mathrm{C}$; IR 
(ATR) $\mathrm{v} / \mathrm{cm}^{-1}$ 3086, $3064\left(\mathrm{C}-\mathrm{H}_{\text {Alke }}\right), 3007\left(\mathrm{C}-\mathrm{H}_{\mathrm{Ar}}\right), 2924$, $2900(\mathrm{C}-\mathrm{H}), 1716(\mathrm{C}=\mathrm{O}$, ester $), 1697(\mathrm{C}=\mathrm{O}$, ketone), $1620\left(\mathrm{C}=\mathrm{C}_{\text {Alke }}\right), 1606$ and $1502\left(\mathrm{C}=\mathrm{C}_{\mathrm{Ar}}\right), 1444\left(\mathrm{CH}_{2}\right), 1247$ and $1141\left(\mathrm{O}-\mathrm{CH}_{2}-\mathrm{O}\right), 927,819,808\left(\mathrm{C}-\mathrm{H}_{\mathrm{Ar}}\right) ;{ }^{1} \mathrm{H}$ NMR $\left(500 \mathrm{MHz}, \mathrm{DMSO}-d_{6}\right) \delta 7.90(\mathrm{~d}, J 7.7 \mathrm{~Hz}, 2 \mathrm{H}, \mathrm{H}-16$ and H-16'), 7.76 (d, J 7.2 Hz, 2H, H-17 and H-17'), 7.45 (dd, J 14.8, 10.1 Hz, 1H, H-3), 7.20 (s, 1H, H-7), 7.03 (t, $J 13.3 \mathrm{~Hz}, 3 \mathrm{H}, \mathrm{H}-4, \mathrm{H}-5$ and $\mathrm{H}-11), 6.91(\mathrm{~d}, J 7.9 \mathrm{~Hz}, 1 \mathrm{H}$, $\mathrm{H}-10), 6.13$ (d, J 15.0 Hz, 1H, H-2), 6.04 (s, 2H, H-12), 5.48 (s, 2H, H-13); ${ }^{13} \mathrm{C}$ NMR (126 MHz, DMSO- $\left.d_{6}\right) \delta 165.32$ (C-1), 118.70 (C-2), 145.70 (C-3), 124.40 (C-4), 140.67 (C-5), 130.21 (C-6), 105.74 (C-7), 147.79 (C-8), 148.09 (C-9), 108.24 (C-10), 122.87 (C-11), 101.11 (C-12), 65.92 (C-13), 192.17 (C-14), 133.02 (C-15), 129.45 (C-16 and C-16'), 131.70 (C-17 and C-17'), 127.59 (C-18).

\section{Computational details}

All DFT calculations were performed using the Gaussian 09 package, version D.01, ${ }^{23}$ at the National Center for High-Performance Computing in São Paulo (CENAPAD-SP). The GaussView 5.0.8 program $^{24}$ was used to construct molecular structures, frontier molecular orbitals and molecular electrostatic potential surfaces.

\section{Conformational study and geometry optimization}

A conformational search protocol was applied for the PC1 compound by using the B3LYP/6-31G(d,p) method in combination with Grimme density functional dispersion correction (DFT-D3). ${ }^{25}$ The D3 corrections were applied to achieve a better description of intramolecular interactions on compounds in the gas phase. The dihedral angles $\mathrm{O}-\mathrm{C}-\mathrm{C}-\mathrm{O}\left(\phi_{1}\right)$ and $\mathrm{C}-\mathrm{C}-\mathrm{O}-\mathrm{C}\left(\phi_{2}\right)$ (see Figure 2$)$ were scanned over their full range using an interval of $10^{\circ}$ between points to generate potential energy surfaces (PES) with 36 points through a relaxed dihedral angle scan.

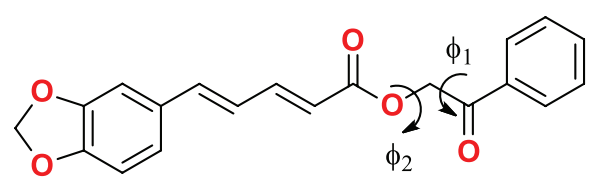

Figure 2. Structure of the PC1 compound with the dihedral angles defined.

The four lowest-energy conformers were optimized in chloroform solution by means of the B3LYP-D3/6-311+G(2d,p) method and using the integral equation formalism polarizable continuum model (IEFPCM) continuum model solvent. ${ }^{26}$ The Gibbs free energies of the conformers were computed at the same theoretical level to calculate the Boltzmann populations.
From the most stable PC1 conformer, the structures of the PC2, PC3 and PC4 compounds were built by the addition of the substituents $\mathrm{NO}_{2}, \mathrm{CH}_{3}$ and $\mathrm{Br}$, respectively, on the phenyl ring. Their geometries were optimized in the gas phase and in DMSO by using the B3LYP-D3/6-311+G(2d,p) method and the IFPCM solvent model. The vibrational frequency was calculated to ensure that the structures are minima on the potential energy surface.

\section{Electronic properties}

The molecular electrostatic potential, frontier molecular orbitals (highest occupied molecular orbital (HOMO) and lowest unoccupied molecular orbital (LUMO)) and DFT chemical reactivity descriptors of the compounds were calculated from a single point by using the B3LYP/6-311+G(2d,p) method. Molecular electrostatic potential surfaces (MEPS) were obtained with fixed values of electronic density (isosurface) of $0.001 \mathrm{e} \mathrm{bohr}^{-3}$. This electronic density value was recommended by Barde et al..$^{27}$ and is considered standard in the calculation of the MPES of several organic molecules. The global chemical reactivity descriptors, such as chemical hardness $(\eta)$, electronic chemical potential $(\mu)$ and electrophilicity $(\omega)$, were evaluated from the HOMO and LUMO energies using the following equations:

$\eta=\frac{E_{\text {LUMO }}-E_{\text {HOMO }}}{2}$

$\mu=\frac{\mathrm{E}_{\mathrm{LUMO}}+\mathrm{E}_{\mathrm{HOMO}}}{2}$

$\omega=\frac{\mu^{2}}{2 \eta}$

\section{NMR calculations}

The ${ }^{1} \mathrm{H}$ and ${ }^{13} \mathrm{C}$ NMR chemical shifts were obtained from single point calculations by using the B3LYP/6-311+G(2d,p) method, from the optimized geometries at the same theoretical level and using the gauge invariant atomic orbital (GIAO) model. ${ }^{28}$ Previous studies show that this functional in combination with the basis set provides good results in calculations of NMR chemical shifts. ${ }^{29,30}$ The formalism of the IEFPCM model for chloroform and DMSO as solvents was used in the NMR calculations. The calculated NMR shielding tensors were converted to chemical shifts by use of empirical scaling factors ${ }^{31}$ that are derived from linear regression analysis for a set of molecules. To assess the performance of the DFT method in predicting the ${ }^{1} \mathrm{H}$ and ${ }^{13} \mathrm{C}$ NMR chemical shifts of the investigated compounds, 
the mean absolute deviation (MAD) was used, which is defined as follows:

$\mathrm{MAD}=\frac{1}{\mathrm{~N}} \sum_{\mathrm{i}}^{\mathrm{N}}\left|\mathrm{x}_{\mathrm{i}}^{\mathrm{cal}}-\mathrm{x}_{\mathrm{i}}^{\exp }\right|$

where $\mathrm{x}_{\mathrm{i}}^{\mathrm{cal}}$ and $\mathrm{x}_{\mathrm{i}}^{\mathrm{exp}}$ are the chemical shifts calculated by the DFT method and its corresponding experimental value, respectively. $\mathrm{N}$ is the total number of chemical shifts associated with each molecular structure.

\section{Antifungal activity}

\section{Test substance}

For microbiological tests, the synthesized compounds were used in emulsion forms, using 5\% dimethylsulfoxide (DMSO) and 2\% Tween 80 (Sigma-Aldrich ${ }^{\circledR}$, São Paulo, Brazil) and completing the volume with sterile distilled water until obtaining the necessary concentrations for each test. ${ }^{32,33}$

\section{Culture mediums}

The culture media used to maintain the fungal strains was Sabouraud dextrose agar (SDA) (Difco Laboratories Ltd, Detroit, USA). For the biological activity tests, Roswell Park Memorial Institute (RPMI-1640) medium was used with L-glutamine and without sodium bicarbonate (Difco Laboratories Ltd, Detroit, USA and INLAB, São Paulo, Brazil). The culture media were prepared according to the manufacturer's instructions.

\section{Microorganisms}

For the biological activity assays of the test products, the following strains were used: Candida albicans ATCC 76645, C. albicans LM-111, C. albicans LM-122, C. tropicalis ATCC-13803, C. tropicalis LM-04, C. krusei LM-656, C. krusei LM-13, Trichophyton rubrum LM-49, Microsporum canis LM-12, and M. gypseum LM-512. The microorganisms belong to MICOTECA of the Mycology Laboratory, Department of Pharmaceutical Sciences (DCF), Health Sciences Center (CCS) of the Federal University of Paraíba (UFPB). The strains were maintained in SDA at $4{ }^{\circ} \mathrm{C}$. For use in the assays, cultures were reactivated in SDA, and colonies were removed for inoculum preparation according to the standard 0.5 McFarland scale, which corresponds to approximately $10^{6}$ colony-forming unit (CFU) $\mathrm{mL}^{-1} \cdot{ }^{34-36}$

\section{Determination of the minimum inhibitory concentration (MIC) \\ The MIC of the substances was determined using the microdilution technique in liquid medium in 96-well}

plates. Initially, $100 \mu \mathrm{L}$ of double-concentrated RPMI broth was distributed to the microdilution plate wells. Subsequently, $100 \mu \mathrm{L}$ of the substances were dispensed into the wells of the plates and diluted sequentially to obtain different substances. Finally, previously standardized fungal inoculums were added. At the same time, controls were performed to prove the viability of the strains (RPMI + fungal inoculums), the sterility of the culture medium (RPMI) and the positive control with amphotericin B $\left(0.034 \mu \mathrm{mol} \mathrm{mL}^{-1}\right)$. The prepared plates were aseptically closed and incubated at a temperature of $35 \pm 2{ }^{\circ} \mathrm{C}$ for $24-48 \mathrm{~h}$ for yeast fungi and 7-14 days at $28 \pm 2{ }^{\circ} \mathrm{C}$ for filamentous fungi. The MIC for each product was defined as the lowest concentration capable of visually inhibiting microbial growth. The result was expressed as the arithmetic mean of the MIC obtained, performed in triplicate.

Determination of minimum fungicidal concentration (MFC) After reading the MIC, aliquots of $10 \mu \mathrm{L}$ of the supernatants were withdrawn from the wells of the microdilution plates at concentrations corresponding to the $\mathrm{MIC}, \mathrm{MIC} \times 2, \mathrm{MIC} \times 4$ and $\mathrm{MIC} \times 8$ of each product for each strain and inoculated into new microdilution plates containing only RPMI medium. The assay was performed in triplicate. The plates were incubated at $35 \pm 2{ }^{\circ} \mathrm{C}$ for $24-48 \mathrm{~h}$ for yeasts and $28 \pm 2{ }^{\circ} \mathrm{C}$ for $7-14$ days for filamentous fungi, and fungal growth was observed. The tests were performed in triplicate and the results expressed as the arithmetic mean of the MFCs obtained. ${ }^{37}$

\section{Results and Discussion}

\section{Chemistry}

The synthesis of target molecules derived from piperine (PC1-PC4) was performed in three synthetic stages, as described in Scheme 1.

In the first step, the piperine (6) obtained from the black pepper through Soxhlet extraction ${ }^{5}$ was hydrolyzed in a basic solution of $20 \% \mathrm{KOH}$ using ethanol as a solvent under reflux for $20 \mathrm{~h}$, obtaining potassium piperate (7) in $93 \%$ yield. In the second step, the preparation of arylacyl bromide $(\mathbf{9 a - 9 d})^{22}$ with a yield between 75 and $80 \%$ was obtained from the reaction between bromine and different substituted acetophenones (8a-8d) using chloroform as a solvent at room temperature. In the third and last stage, compounds PC1-PC4 were obtained from the $\mathrm{S}_{\mathrm{N}} 2$ nucleophilic substitution reaction between arylacyl bromide (9a-9d) and potassium piperate (7) using dimethylformamide (DMF) as a solvent at a temperature of 
<smiles>[X]OC(=O)/C=C/C=C/c1ccc2c(c1)OC(C#CC)CO2</smiles>

(6)

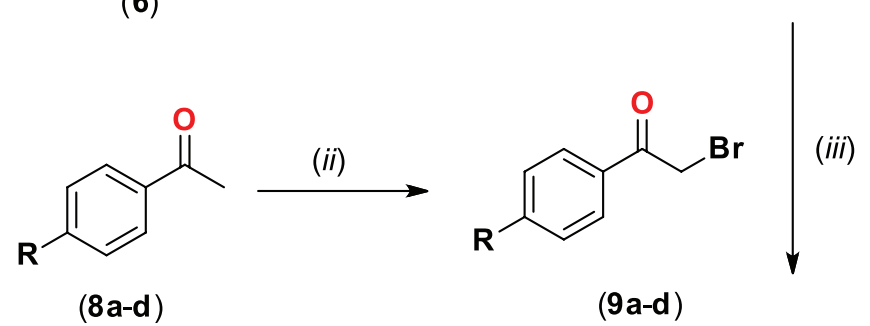<smiles>[R]c1ccc(C(=O)COC(=O)C=CC=Cc2ccc3c(c2)OCO3)cc1</smiles>

1: $\mathrm{R}=\mathrm{H} ; 2: \mathrm{R}=\mathrm{NO}_{2} ; 3: \mathrm{R}=\mathrm{CH}_{3} ; 4: \mathrm{R}=\mathrm{Br}$

Scheme 1. Synthetic route for the synthesis of the target molecules: reagents and conditions: (i) $\mathrm{KOH} 20 \%, \mathrm{EtOH}, \mathrm{reflux}, 20 \mathrm{~h}$, yield $93 \%$; (ii) $\mathrm{Br}_{2}, \mathrm{CHCl}_{3}$, rt, overnight, yield 75-80\%; (iii) DMF, $100{ }^{\circ} \mathrm{C}, 24 \mathrm{~h}$, yield 50-65\%.

$100^{\circ} \mathrm{C}$ for $24 \mathrm{~h}$. The products obtained with yields between 50 and $65 \%$ were purified using the recrystallization method in a solvent mixture of DMF/water (8:2).

The structures of the compounds derived from piperine (PC1-PC4) were characterized by infrared (IR) and ${ }^{1} \mathrm{H}$ and ${ }^{13} \mathrm{C}$ nuclear magnetic resonance (NMR) spectroscopy. In the infrared spectra of the compounds derived from piperine, two stretches attributed to carbonyls are observed, one carbonyl in the ester group that appears at approximately $1716-1712 \mathrm{~cm}^{-1}$ and one carbonyl in the ketone group at approximately $1703-1689 \mathrm{~cm}^{-1}$. The presence of alkene $\mathrm{C}-\mathrm{H}$ and aromatic $\mathrm{C}-\mathrm{H}$ stretches can be observed at approximately $3105-3062 \mathrm{~cm}^{-1}$ and $3070-3000 \mathrm{~cm}^{-1}$, respectively. In the 2933-2900 region, aliphatic $\mathrm{C}-\mathrm{H}$ stretches are observed. stretches attribute to the $\mathrm{C}=\mathrm{C}$ of aromatic rings in the range of $1606-1483 \mathrm{~cm}^{-1}$ are observed, while stretching of the of $\mathrm{C}=\mathrm{C}$ of alkenes can be observed at approximately $1620 \mathrm{~cm}^{-1}$. The asymmetric and symmetrical stretching of the methylenedioxy group varies between 1257-1226 and $1143-1128 \mathrm{~cm}^{-1}$, respectively. In the PC2 compound, asymmetric and symmetrical stretching at approximately 1523 and $1346 \mathrm{~cm}^{-1}$ can be observed, respectively, for the $\mathrm{NO}_{2}$ group.

In the ${ }^{1} \mathrm{H}$ NMR spectrum for all compounds (PC1-PC4), two characteristic signals present in the structures were shown in the form of singlets: a singlet for two methylene protons $(\mathrm{H}-13)$ in the range of 5.56-5.42 ppm and another singlet for two methylene protons referring to the methylenedioxy group $(\mathrm{H}-12)$ in the range of
6.04-5.98 ppm. The protons present in the aromatic ring and the olefinic protons resonated in the region 8.35-6.10 ppm. In the $\mathbf{P C} 3$ spectra, the methyl group was characterized by a singlet at $2.40 \mathrm{ppm}$. For the ${ }^{13} \mathrm{C}$ NMR spectrum for all compounds, the carbon from the carbonyl corresponding to the ketone was characterized at approximately $192 \mathrm{ppm}$, and the carbonyl corresponding to the ester was characterized at approximately $166 \mathrm{ppm}$. The compounds showed characteristic signs of methylene carbons: one peak in the region of 66.3-65.9 ppm referring to C-13 and another peak in the region of 101.4-101.1 ppm referring to C-12 (methylenedioxy). The signals attributed to the aromatic carbons and olefinic are in the range 148.7-105.72 ppm. In the spectra of compound PC3, an additional signal in the aliphatic region at $28.87 \mathrm{ppm}$ for the carbon of the methyl group was observed.

\section{Conformational analysis}

An understanding of molecular conformation has been shown to be fundamental to spectroscopy, material sciences, organic synthesis and biochemistry. ${ }^{38}$ Since the experimental structural determination of new piperine derivatives was not possible, a conformation search of the PC1 compound was performed by using quantum mechanical calculations. The potential energy surfaces were calculated by the B3LYP/6-31G(d,p) method with the dispersion contribution obtained from the D3 correction and are shown in Figures S16 and S17 (Supplementary 

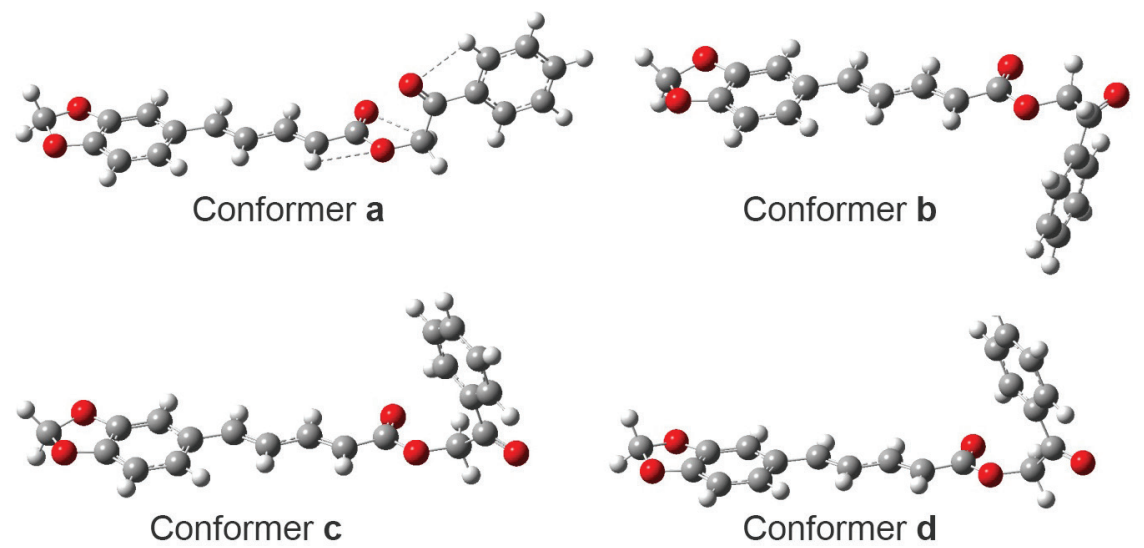

Figure 3. Optimized geometries of the four lowest energy conformers of PC1 compound, calculated by B3LYP-D3/6-311+G(2d,p) in chloroform.

Information (SI) section). The lowest energy conformers were optimized using the B3LYP-D3/6-311+G(2d,p) method in chloroform solution and are shown in Figure 3. Only the conformations in which piperate moieties are in the same $\pi$-plane were considered.

The relative Gibbs energies, Boltzmann population and selected dihedral angles for conformers are listed in Table 1.

Table 1. Relative Gibbs energy $(\Delta \mathrm{G})$, Boltzmann population (at $298.15 \mathrm{~K}$ ) and dihedral angle of lowest-energy conformers of the PC1 compound calculated by the B3LYP-D3/6-311+G(2d,p) method

\begin{tabular}{lccc}
\hline Conformer & $\Delta \mathrm{G} /\left(\mathrm{kJ} \mathrm{mol}^{-1}\right)$ & Population / \% & $\begin{array}{c}\mathrm{C}-\mathrm{C}-\mathrm{O}-\mathrm{C} \text { angle } \\
/ \text { degree }\end{array}$ \\
\hline a & 0.00 & 45.45 & 78.7 \\
b & 0.74 & 33.68 & -62.9 \\
c & 3.59 & 10.70 & 128.4 \\
d & 3.71 & 10.17 & 128.3 \\
\hline
\end{tabular}

Conformer a was predicted by DFT calculations to be approximately $0.74-3.71 \mathrm{~kJ} \mathrm{~mol}^{-1}$ more stable than the other conformers and to contribute approximately $45.5 \%$ of the Boltzmann population at $298.15 \mathrm{~K}$ (see Table 1). The main factors that determine the stability of the conformers are apparently the $\mathrm{C}=\mathrm{O} \cdots \mathrm{H}$ and $\mathrm{C}_{2} \mathrm{O} \cdots \mathrm{H}$ intramolecular interactions (see Figure 3, conformer a) and steric effects of the 2-pheyl-2-oxoethyl group. Furthermore, pronounced conjugation on the piperate moiety plays an important role in determining the stability of the conformers.

From the most stable conformer a, the structures of PC2, PC3 and PC4 compounds were built by the addition of the substituents $\mathrm{NO}_{2}, \mathrm{CH}_{3}$ and $\mathrm{Br}$ to the phenyl ring, respectively. The geometries were optimized in the gas phase and in DMSO solvent by using the B3LYP-D3/6-311+G(2d,p) method and used in the calculation of their electronic and spectroscopic properties.

\section{Electronic properties}

Electronic proprieties of the piperine analogs were calculated at the B3LYP/6-311+G(2d,p) theoretical level to obtain information on reactivity, stability and the electrophilic and nucleophilic sites in the molecules.

The molecular electrostatic potential (MEP) provides information about the charge distribution on the molecules, and it is very useful in understanding the sites of electrophilic attacks and nucleophilic reactions for the study of biological recognition processes and hydrogen bonding interactions ${ }^{39,40}$ To predict the molecular reactive sites, the MEPs for the studied compounds were calculated and are shown in Figure 4.

The negative regions in red are related to electrophilic reactivity and positive regions in blue are related to nucleophilic reactivity. As seen from the MEP maps of the compounds, the higher negative regions include carbonyl groups. The positive regions are over $\mathrm{CH}_{2}$ in the 1,3-benzodioxole group. For the PC2 molecule, the most positive region includes $\mathrm{C}-\mathrm{C}$ bonds in the 4-nitrophenyl group. These results show that the $\mathrm{NO}_{2}$ substituent in PC2 increases its nucleophilic reactivity in comparison with other piperine derivatives.

Frontier molecular orbitals and their energies are important quantum chemical parameters used for predicting the most reactive regions in molecular systems. In addition, the energy gap between the highest occupied molecular orbital (HOMO) and lowest unoccupied molecular orbital (LUMO) reflects the biological activity of the molecule. A molecule with a small frontier orbital gap is more polarizable and commonly has high chemical reactivity and low kinetic stability. ${ }^{41}$

Figure 5 shows the HOMO and LUMO for PC1 and PC2 compounds. In the PC1 molecule, both its HOMO and LUMO frontier orbitals are delocalized over the piperate moiety. Similar frontier orbitals are observed 

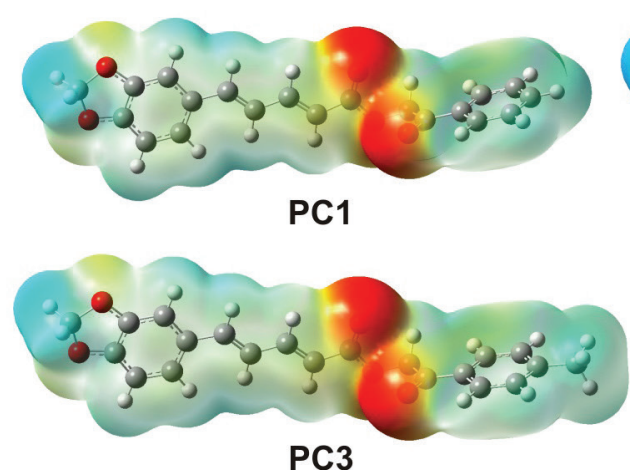
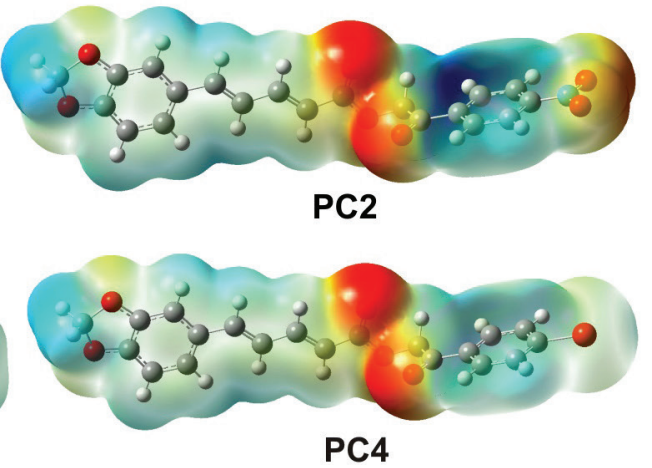

Figure 4. Molecular electrostatic potential for piperine derivatives, calculated at the B3LYP/6-311+G(2d,p) level.

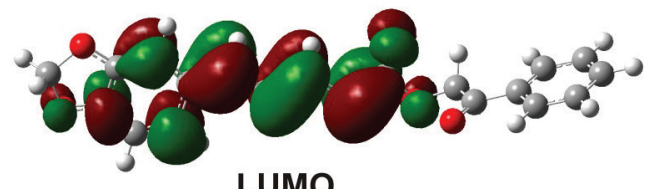

LUMO

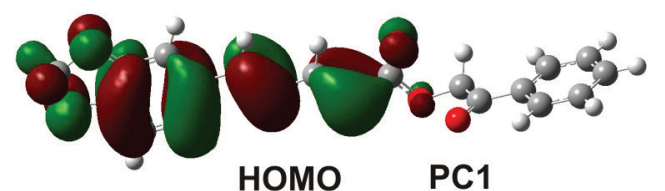

HOMO PC1
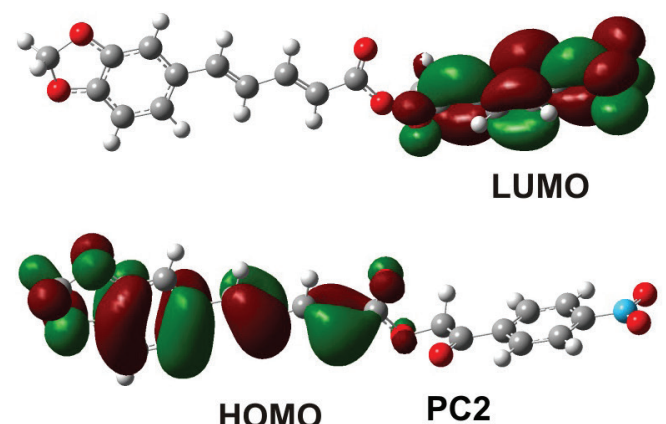

Figure 5. HOMO and LUMO plots for PC1 and PC2 compounds.

for the PC1, PC3 and PC4 molecules (see Figure S18, SI section).

On the other hand, the LUMO of PC2 is localized over the 2-(4-nitrophenyl)-2-oxoethyl moiety (Figure 5). Hence, the HOMO-LUMO transition on the PC2 compound implies an electron density transfer from the piperate to the 2-(4-nitrophenyl)-2-oxoethyl moiety.

DFT chemical reactivity descriptors of the compounds were calculated by means of the B3LYP/6-311+G(2d,p) method and are listed in Table 2.

Table 2. DFT descriptors calculated at the B3LYP/6-311+G(2d,p) level

\begin{tabular}{lcccccc}
\hline \multirow{2}{*}{ Compound } & \multicolumn{7}{c}{ Quantum descriptor / eV } \\
\cline { 2 - 7 } & $\mathrm{E}_{\text {номо }}$ & $\mathrm{E}_{\text {Luмо }}$ & $\Delta \mathrm{E}$ & $\eta$ & $\mu$ & $\omega$ \\
\hline PC1 & -5.77 & -2.24 & 3.54 & 1.77 & -2.93 & 2.42 \\
PC2 & -5.90 & -3.43 & 2.40 & 1.20 & -2.98 & 3.69 \\
PC3 & -5.74 & -2.21 & 3.54 & 1.77 & -2.91 & 2.40 \\
PC4 & -5.81 & -2.30 & 3.52 & 1.76 & -2.95 & 2.47 \\
\hline
\end{tabular}

eV: electron-volts; $\mathrm{E}_{\text {номо }}$ : HOMO energy; $\mathrm{E}_{\mathrm{LUMO}}$ : LUMO energy; $\Delta \mathrm{E}$ : energy gap HOMO-LUMO; $\eta$ : hardness; $\mu$ : electronic chemical potential; $\omega$ : electrophilicity.

HOMO and LUMO energies are associated with the electron donor and acceptor capacities of the molecule, respectively. Overall, the greater the HOMO energy is (smaller negative value), the superior the capacity to donate electrons. The smallest energy gap HOMO-LUMO $(\Delta \mathrm{E})$ for the PC2 compound increases its reactive nature and polarizability.

The global electrophilicity index $(\omega)$, proposed by Parr et al. ${ }^{42}$ is a measure of the energy stabilization of a molecule when it acquires an additional electronic charge from the environment. The electrophilicity $\omega$ index encompasses both the tendency of an electrophile to acquire an extra electron density (chemical potential, $\mu$ ) and the resistance of a molecule to exchange electron density with the environment (hardness, $\eta$ ). It contains information about electron transfer, given by $\mu$, and molecular stability, given by $\eta \cdot{ }^{43}$ Piperine derivatives show similar electrophilicity values (2.40-2.47 eV), except for the PC2 compound, which is the strongest electrophilic among the molecules investigated.

\section{NMR calculation}

The ${ }^{1} \mathrm{H}$ and ${ }^{13} \mathrm{C}$ experimental spectra of the piperine analog were recorded in deuterated chloroform and DMSO solution with tetramethysilane (TMS) as the internal standard. The chemical shifts were calculated using the B3LYP functional with the $6-311+\mathrm{G}(2 \mathrm{~d}, \mathrm{p})$ basis set in chloroform for the PC1 compound and DMSO (PC2-PC4) 
in the framework of the IEFPCM solvent model. The ${ }^{13} \mathrm{C}$ and ${ }^{1} \mathrm{H}$ chemical shifts calculated by the DFT method and adjusted by scale factors ${ }^{31}$ were compared with experimental values. Table 3 lists the ${ }^{13} \mathrm{C}$ chemical shifts for piperine derivatives, and the numbering of each atom used in the investigation is shown in Figure 6.

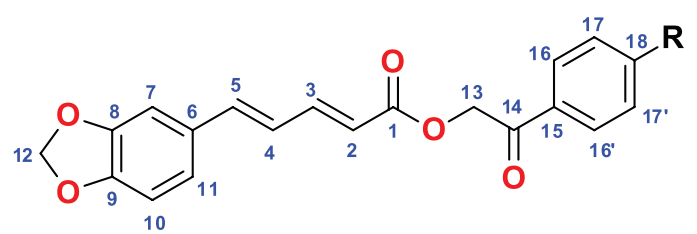

Figure 6. The numbering system used in piperine derivatives for ${ }^{1} \mathrm{H}$ and ${ }^{13} \mathrm{C}$ NMR analysis, wherein $\mathrm{R}=\mathrm{H}, \mathrm{NO}_{2}, \mathrm{CH}_{3}$ or $\mathrm{Br}$.

The carbon chemical shift data for all compounds showed similar results, with a mean absolute deviation (MAD) in the range of 2.1-3.3 ppm. The largest MAD was obtained for the PC4 compound, and it was associated with poor prediction of the C18 carbon signal by DFT calculation (deviation of $19.1 \mathrm{ppm}$ ). When the $\mathrm{C} 18$ carbon signal for this compound is excluded in the calculation of MAD, the new value is $2.4 \mathrm{ppm}$. These errors can be attributed to the lack of relativistic effects in the calculation of chemical shifts of carbon atoms linked to halogens ${ }^{44}$ resulting in the elimination of these data in the calculation of the ${ }^{13} \mathrm{C}$ NMR scaling factors.

For other piperine derivatives, the largest deviation was associated with $\mathrm{C} 2, \mathrm{C} 4$ and $\mathrm{C} 11$ carbons. In the PC1 compound, the maximum deviation was for $\mathrm{C} 4$ carbon at $6.8 \mathrm{ppm}$, while for $\mathbf{P C 2}$, it was associated with $\mathrm{C} 2$ carbon at $5.8 \mathrm{ppm}$. For the $\mathbf{P C} 3$ compound, the maximum deviation was for $\mathrm{C} 11$ carbon at $5.8 \mathrm{ppm}$. These deviations can be mainly assigned to the use of the implicit solvent model (IEFPCM) in the calculation of NMR chemical shifts. This model neglects the solute-solvent interactions present in experimental measurements. ${ }^{30}$

The mean deviation between experimental ${ }^{1} \mathrm{H}$ NMR chemical shifts and their corresponding calculated values for piperine derivatives were larger in DMSO solvent than chloroform (Table 4).

The results suggest that the solute-solvent intermolecular interactions are stronger in DMSO. For both compounds, the largest deviations observed in the range $0.33-0.62 \mathrm{ppm}$

Table 3. The experimental (Exp.) and calculated (Calcd.) ${ }^{13} \mathrm{C}$ NMR chemical shifts of piperine derivatives in chloroform for PC1 and DMSO (PC2-PC4) solvents using the B3LYP/6-311+G(2d,p) method

\begin{tabular}{|c|c|c|c|c|c|c|c|c|}
\hline \multirow{2}{*}{ Assignment } & \multicolumn{2}{|c|}{ PC1 } & \multicolumn{2}{|c|}{ PC2 } & \multicolumn{2}{|c|}{$\mathrm{PC} 3$} & \multicolumn{2}{|c|}{ PC4 } \\
\hline & Calcd. / ppm & Exp. / ppm & Calcd. / ppm & Exp. / ppm & Calcd. / ppm & Exp. / ppm & Calcd. / ppm & Exp. / ppm \\
\hline $\mathrm{C} 1$ & 166.2 & 166.4 & 165.6 & 165.3 & 165.8 & 165.4 & 165.7 & 165.3 \\
\hline $\mathrm{C} 2$ & 115.0 & 119.1 & 112.7 & 118.5 & 113.5 & 118.9 & 113.1 & 118.7 \\
\hline $\mathrm{C} 3$ & 148.6 & 146.9 & 147.6 & 145.9 & 147.1 & 145.6 & 147.3 & 145.7 \\
\hline $\mathrm{C} 4$ & 117.6 & 124.5 & 120.7 & 124.4 & 120.8 & 124.4 & 120.7 & 124.4 \\
\hline $\mathrm{C} 5$ & 143.1 & 140.9 & 143.5 & 140.8 & 143.1 & 140.6 & 143.3 & 140.7 \\
\hline C6 & 127.5 & 130.5 & 127.9 & 130.2 & 128.0 & 130.2 & 128.0 & 130.2 \\
\hline $\mathrm{C} 7$ & 106.9 & 106.0 & 109.3 & 105.7 & 109.0 & 105.7 & 109.1 & 105.7 \\
\hline $\mathrm{C} 8$ & 147.6 & 148.3 & 146.7 & 147.8 & 146.6 & 147.8 & 146.8 & 147.8 \\
\hline C9 & 147.6 & 148.7 & 148.7 & 148.1 & 148.3 & 148.1 & 148.5 & 148.1 \\
\hline $\mathrm{C} 10$ & 109.8 & 108.6 & 106.1 & 108.2 & 106.1 & 108.2 & 106.0 & 108.2 \\
\hline C11 & 126.6 & 123.1 & 117.3 & 122.9 & 117.0 & 122.9 & 117.0 & 122.9 \\
\hline $\mathrm{C} 12$ & 103.3 & 101.4 & 103.0 & 101.1 & 102.9 & 101.1 & 102.7 & 101.1 \\
\hline $\mathrm{C} 13$ & 66.0 & 66.0 & 66.1 & 66.3 & 65.7 & 65.9 & 65.7 & 65.9 \\
\hline $\mathrm{C} 14$ & 191.2 & 192.4 & 191.2 & 192.4 & 190.7 & 192.2 & 190.5 & 192.2 \\
\hline $\mathrm{C} 15$ & 132.9 & 134.4 & 135.5 & 138.6 & 127.6 & 131.5 & 129.1 & 133.0 \\
\hline C16 & 124.1 & 128.8 & 127.0 & 129.0 & 125.9 & 127.5 & 127.2 & 129.5 \\
\hline $\mathrm{C} 17$ & 128.3 & 127.8 & 123.0 & 123.6 & 126.2 & 129.1 & 129.2 & 131.7 \\
\hline $\mathrm{C} 18$ & 131.7 & 133.8 & 148.6 & 150.2 & 146.0 & 144.0 & 146.7 & 127.6 \\
\hline $\mathrm{CH}_{3}$ & & & & & 21.1 & 20.9 & & \\
\hline MAD & & 2.1 & & 2.2 & & 2.4 & & 3.3 \\
\hline
\end{tabular}

MAD: mean absolute deviation. 
Table 4. The experimental (Exp.) and calculated (Calcd.) ${ }^{1} \mathrm{H}$ NMR chemical shifts of piperine derivatives in chloroform PC1 and DMSO (PC2-PC4) solvents using the B3LYP/6-311+G(2d,p) method

\begin{tabular}{|c|c|c|c|c|c|c|c|c|}
\hline \multirow{2}{*}{ Assignment } & \multicolumn{2}{|c|}{ PC1 } & \multicolumn{2}{|c|}{ PC2 } & \multicolumn{2}{|c|}{ PC3 } & \multicolumn{2}{|c|}{ PC4 } \\
\hline & Calcd. / ppm & Exp. / ppm & Calcd. / ppm & Exp. / ppm & Calcd. / ppm & Exp. / ppm & Calcd. / ppm & Exp. / ppm \\
\hline$\overline{\mathrm{H} 2}$ & 5.91 & 6.10 & 5.93 & 6.14 & 5.94 & 6.14 & 5.94 & 6.13 \\
\hline H3 & 7.56 & 7.51 & 7.55 & 7.46 & 7.53 & 7.45 & 7.53 & 7.45 \\
\hline $\mathrm{H} 4$ & 6.93 & 6.78 & 6.95 & 7.03 & 6.95 & 7.03 & 6.96 & 7.03 \\
\hline H5 & 6.77 & 6.78 & 6.84 & 7.03 & 6.81 & 7.03 & 6.82 & 7.03 \\
\hline H7 & 6.63 & 7.00 & 6.65 & 7.20 & 6.63 & 7.20 & 6.63 & 7.20 \\
\hline H10 & 6.69 & 6.92 & 6.69 & 6.91 & 6.70 & 6.91 & 6.69 & 6.91 \\
\hline H11 & 7.40 & 6.78 & 7.36 & 7.03 & 7.38 & 7.03 & 7.37 & 7.03 \\
\hline H12 & 5.95 & 5.98 & 5.99 & 6.04 & 5.92 & 6.04 & 5.97 & 6.04 \\
\hline H13 & 5.41 & 5.42 & 5.35 & 5.56 & 5.36 & 5.47 & 5.30 & 5.48 \\
\hline H16 & 7.92 & 7.94 & 8.08 & 8.20 & 7.79 & 7.36 & 7.81 & 7.90 \\
\hline H17 & 7.40 & 7.51 & 8.43 & 8.35 & 7.31 & 7.86 & 7.48 & 7.76 \\
\hline H18 & 7.57 & 7.61 & & & & & & \\
\hline $\mathrm{CH}_{3}$ & & & & & 2.26 & 2.40 & & \\
\hline MAD & & 0.15 & & 0.19 & & 0.27 & & 0.21 \\
\hline
\end{tabular}

MAD: mean absolute deviation.

were for the $\mathrm{H} 7$ and $\mathrm{H} 11$ protons of the 1,3-benzodioxole group. For the PC1 compound, the largest deviation was for the H11 proton at $0.62 \mathrm{ppm}$, while for PC2, PC3 and PC4, they were associated with the $\mathrm{H} 7$ proton at $0.55,0.57$ and $0.57 \mathrm{ppm}$, respectively.

As can be observed, for all piperine derivatives, there is good agreement between the experimental and calculated ${ }^{1} \mathrm{H}$ chemical shifts $(\mathrm{MAD}<0.3 \mathrm{ppm})$. The low MDA for the PC1 compound indicates better DFT calculation performance in chloroform solvent.

\section{Antifungal activity}

The preliminary study on antifungal activity in vitro of compounds derived from piperine PC1-PC4 was evaluated by the microdilution method with 10 strains of pathogenic fungi divided into yeast (Candida albicans ATCC 76645, C. albicans LM-111, C. albicans LM-122, C tropicalis ATCC-13803, C. tropicalis LM-04, C. krusei LM-656, C. krusei LM-13) and filamentous fungi (T. rubrum LM-49, Microsporum canis LM-12, M. gypseum LM-512) using amphotericin B $\left(0.034 \mu \mathrm{mol} \mathrm{mL} L^{-1}\right)$ as the standard drug. Of the four compounds tested, only PC4 showed antifungal activity in seven of the ten strains tested (Table 5).

PC4 showed a minimum inhibitory concentration of

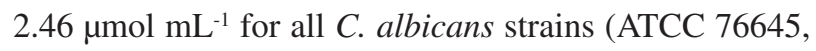
LM-111 and LM-122). For the C. krusei strains (LM-656 and LM-13), the MIC was $1.23 \mu \mathrm{mol} \mathrm{mL} \mathrm{m}^{-1}$. For filamentous fungi, the compound showed a minimum inhibitory

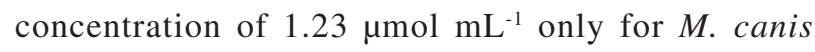

Table 5. Antifungal activity (MIC and MFC values) of compounds PC1-PC4

\begin{tabular}{|c|c|c|c|c|c|c|c|c|}
\hline \multirow[b]{2}{*}{ Microorganism } & \multicolumn{2}{|c|}{ PC1 } & \multicolumn{2}{|c|}{ PC2 } & \multicolumn{2}{|c|}{ PC3 } & \multicolumn{2}{|c|}{ PC4 } \\
\hline & $\begin{array}{c}\mathrm{MIC} / \\
\left(\mu \mathrm{mol} \mathrm{mL} L^{-1}\right)\end{array}$ & $\begin{array}{c}\mathrm{MFC} / \\
\left(\mu \mathrm{mol} \mathrm{mL} L^{-1}\right)\end{array}$ & $\begin{array}{c}\text { MIC / } \\
\left.(\mu \mathrm{mol} \mathrm{mL})^{-1}\right)\end{array}$ & $\begin{array}{c}\mathrm{MFC} / \\
\left(\mu \mathrm{mol} \mathrm{mL} L^{-1}\right)\end{array}$ & $\begin{array}{c}\mathrm{MIC} / \\
\left.(\mu \mathrm{mol} \mathrm{mL})^{-1}\right)\end{array}$ & $\begin{array}{c}\mathrm{MFC} / \\
\left(\mu \mathrm{mol} \mathrm{mL} L^{-1}\right)\end{array}$ & $\begin{array}{c}\mathrm{MIC} / \\
\left.(\mu \mathrm{mol} \mathrm{mL})^{-1}\right)\end{array}$ & 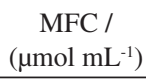 \\
\hline C. a. ATCC 76645 & + & + & + & + & + & + & 2.46 & 19.68 \\
\hline c. a. LM-111 & + & + & + & + & + & + & 2.46 & 19.68 \\
\hline C. a. LM-122 & + & + & + & + & + & + & 2.46 & 19.68 \\
\hline C. t. ATCC-13803 & + & + & + & + & + & + & + & + \\
\hline C. $t . \mathrm{LM}-04$ & + & + & + & + & + & + & + & + \\
\hline C. $k . \mathrm{LM}-656$ & + & + & + & + & + & + & 1.23 & 9.84 \\
\hline C. $k . \mathrm{LM}-13$ & + & + & + & + & + & + & 1.23 & 9.84 \\
\hline T. $r . \mathrm{LM}-49$ & + & + & + & + & + & + & + & + \\
\hline M. c. LM-12 & + & + & + & + & + & + & 1.23 & 9.84 \\
\hline M. g. LM-512 & + & + & + & + & + & + & 1.23 & 9.84 \\
\hline
\end{tabular}

C. a.: Candida albicans; C. t.: Candida tropicalis; C. k.: Candida krusei; T. $r$ : Trichophyton rubrum; M. c.: Microsporum canis; M. g.: Microsporum gypseum; MIC: minimum inhibitory concentration; MFC: minimum fungicide concentration. +: indicates growth of the microorganism. 
LM-12 and M. gypseum LM-512. However, for all of the aforementioned situations, it is possible to observe the bioactive potential of the $\mathbf{P C} 4$ compound, which was also evidenced by revealing an excellent MIC against yeast and filamentous fungi for this work. With the need to further investigate the real dimension of its antifungal potential, a minimum fungicide concentration (MFC) assay was carried out. The MFC for PC4 against the strains under study was found to vary between 9.84 and $19.68 \mu \mathrm{mol} \mathrm{mL} \mathrm{mL}^{-1}$. This behavior of different sensitivities of the strains is related to individual particularities of each species and strain. A substance with antifungal activity can have a fungistatic or fungicidal effect, being considered fungistatic when it is able to inhibit or delay fungal growth and fungicidal when it promotes cell death. According to Siddiqui et al., 45 if the MFC/MIC ratio results in a value $\leq 4$, the effect is fungicidal. However, if this ratio is $>4$, the substance has a fungistatic profile. When analyzing the nature of the antifungal action of the PC4 compound, it was revealed that it is of the fungistatic type, since the MFC/MIC ratio obtained was 8 .

\section{Conclusions}

Four new piperine derivatives were synthesized and characterized using IR and ${ }^{1} \mathrm{H}$ and ${ }^{13} \mathrm{C}$ NMR spectroscopic techniques. The geometries of the ground state and the electronic and NMR spectroscopic properties of piperine derivatives were computed by using the B3LYP-D3/6-311+G(2d,p) and B3LYP/6-311+G(2d,p) methods. The ${ }^{1} \mathrm{H}$ and ${ }^{13} \mathrm{C}$ NMR chemical shifts were calculated and compared with the experimental values. The DFT study indicates that the methyl and bromine substituents on the phenyl ring do not have a significant influence on the chemical reactivity and stability of their compounds. On the other hand, the nitro group contributes to the high reactivity of the PC2 compound. The MPE maps suggest that the carbonyl groups are the main regions of electrophilic reactivity of the compounds. In addition, the ${ }^{1} \mathrm{H}$ and ${ }^{13} \mathrm{C}$ NMR chemical shifts calculated by the B3LYP method showed good agreement with the experimental values. In addition, all compounds were evaluated in vitro against different fungi, and only the PC4 compound showed inhibition against seven of the ten strains tested, with MICs ranging from 1.23-2.46 $\mu \mathrm{mol} \mathrm{mL}^{-1}$, and the compound had a fungistatic effect.

\section{Supplementary Information}

Supplementary Information is available free of charge at http://jbcs.sbq.org.br as PDF file.

\section{Acknowledgments}

The authors gratefully acknowledge the financial support from the following Brazilian agencies, institutes and networks: Instituto Nacional de Ciência e Tecnologia de Nanotecnologia para Marcadores Integrados (INCTINAMI), Conselho Nacional de Desenvolvimento Científico e Tecnológico (CNPq), Coordenação de Aperfeiçoamento de Pessoal de Nível Superior-Brasil (CAPES), Programa de Apoio a Núcleos de Excelência (PRONEX-FACEPE) and Financiadora de Estudos e Projetos (FINEP). The authors also acknowledge the physical structure and computational support provided by Universidade Federal da Paraíba (UFPB) and the computer resources of Centro Nacional de Processamento de Alto Desempenho em São Paulo (CENAPAD-SP). The authors also thank Laboratório Multiusuário de Caracterização e Análise (LMCA) at Universidade Federal da Paraíba (UFPB) for carrying out the NMR spectra of hydrogen and carbon.

This study was financed in part by the Coordenação de Aperfeiçoamento de Pessoal de Nível Superior-Brasil (CAPES) through the research project Bioinformática Estrutural de Proteínas: Modelos, Algoritmos e Aplicações Biotecnológicas (Edital Biologia Computacional 51/2013, processo AUXPE1375/2014 da CAPES). G. B. R. acknowledges support from the Brazilian National Council for Scientific and Technological Development (CNPq grant No. 309761/2017-4).

\section{Author Contributions}

P. F. A.-F., J. S. S. J., B. F. L. and E. P. S. M. conceived and designed the experiment; J. S. S. J., F. S. A., R. F. O. and E. O. T. performed the experiments; J. S. S. J., E. O. T., R.F. O. and H.D. S. S. analyzed the data; L. V. C. and E. O. L. performed the antifungal study; E. P. S. M. and G. B. R. performed the computational study; J. S. S. J., H. D. S. S., E. P. S. M. and B. F. L. participated in writing-original draft preparation; J. S. S. J., E. P. S. M., G. B. R., J. M. B.-F. and P. F. A.-F. participated in writing-review and editing.

\section{References}

1. Aldholmi, M.; Marchand, P.; Ourliac-Garnier, I.; Le Pape, P.; Ganesan, A.; Pharmaceuticals 2019, 12, 182.

2. Marquez, L.; Quave, C. L.; Antibiotics 2020, 9, 150.

3. Arif, T.; Bhosale, J. D.; Kumar, N.; Mandal, T. K.; Bendre, R. S.; Lavekar, G. S.; Dabur, R.; J. Asian Nat. Prod. Res. 2009, $11,621$.

4. Chandra, H.; Bishnoi, P.; Yadav, A.; Patni, B.; Mishra, A. P.; Nautiyal, A. R.; Plants 2017, 6, 16. 
5. Santos, J.; Brito, M.; Ferreira, R.; Moura, A. P.; Sousa, T.; Batista, T.; Mangueira, V.; Leite, F.; Cruz, R.; Vieira, G.; Lira, B.; Athayde-Filho, P.; Souza, H.; Costa, N.; Veras, R.; BarbosaFilho, J. M.; Magalhães, H.; Sobral, M.; Int. J. Mol. Sci. 2018, 19, 2594.

6. Ameh, S. J.; Obodozie, O. O.; Inyang, U. S.; Abubakar, M. S.; Garba, M. In Nuts and Seeds in Health and Disease Prevention, $1^{\text {st }}$ ed.; Academic Press: San Diego, United States, 2011, p. 333.

7. Jumpa-ngern, P.; Kietinun, S.; Sakpakdeejaroen, I.; Cheomung, A.; Na-Bangchang, K.; Afr. J. Pharm. Pharmacol. 2013, 7, 560.

8. Feng, G.; Chen, M.; Ye, H. C.; Zhang, Z. K.; Li, H.; Chen, L. L.; Chen, X. L.; Yan, C.; Zhang, J.; Ind. Crops. Prod. 2019, $132,41$.

9. Jeon, H. J.; Kim, K.; Kim, Y. D.; Lee, S. E.; Appl. Biol. Chem. 2019, 62, 63.

10. Antonio, A. S.; Fonseca, D. G.; Mendes, A. J. B.; Wiedemann, L. S. M.; Veiga-Junior, V. F.; J. Braz. Chem. Soc. 2019, 30, 1115.

11. Mgbeahuruike, E. E.; Stålnacke, M.; Vuorela, H.; Holm, Y.; Antibiotics 2019, 8, 55.

12. Dhargawe, N.; Mahakalkar, S.; Mohod, B.; Raj, J. P.; Pharmacogn. Res. 2020, 12, 176.

13. Vieira-Araújo, F. M.; Rondon, F. C. M.; Vieira, I. G. P.; Mende, F. N. P.; Freitas, J. C. C.; Morais, S. M.; Exp. Parasitol. 2018, $188,79$.

14. Samuel, M.; Oliver, S. V.; Coetzee, M.; Brooke, B. D.; Parasites Vectors 2016, 9, 238.

15. Tiwari, A.; Mahadik, K. R.; Gabhe, S. Y.; Medicine Drug Discovery 2020, 7, 100027.

16. Wang, J.; Wang, W.; Xiong, H.; Song, D.; Cao, X.; BMC Chem. 2020, 14, 24.

17. Tantawy, A. H.; Farag, S. M.; Hegazy, L.; Jiang, H.; Wang, M.-Q.; Bioorg. Chem. 2020, 94, 103464.

18. Franklim, T. N.; Freire-de-Lima, L.; Chaves, O. A.; LaRocquede-Freitas, I. F.; da Silva-Trindade, J. D.; Netto-Ferreira, J. C.; Freire-de-Lima, C. G.; Decoté-Ricardo, D.; Previato, J. O.; Mendonça-Previato, L.; de Lima, M. E. F.; J. Braz. Chem. Soc. 2019, 30, 1378.

19. Kharbanda, C.; Alam, M. S.; Hamid, H.; Javed, K.; Bano, S.; Ali, Y.; Dhulap, A.; Alan, P.; Pasha, M. A. Q.; Chem. Biol. Drug Des. 2016, 88, 354.

20. Ferreira, R. C.; Batista, T. M.; Duarte, S. S.; Silva, D. K. F.; Lisboa, T. M. H.; Cavalcanti, R. F. P.; Leite, F. C.; Mangueira, V. M.; Souza, T. K. G.; de Abrantes, R. A.; Trintade, E. O.; Athayde-Filho, P. F.; Brandão, M. C. R.; Medeiros, K. C. P.; Farias, D. F.; Sobral, M. S.; Biomed. Pharmacother. 2020, 128, 110247.

21. Ikan, R.; Natural Products: A Laboratory Guide, $2^{\text {nd }}$ ed.; Academic Press: San Diego, USA, 1991.

22. Elejalde, N.-R.; Macías, M.; Castillo, J.-C.; Sortino, M.; Svetaz, L.; Zacchino, S.; Portilla, J.; ChemistrySelect 2018, 3, 5220.

23. Frisch, M. J.; Trucks, H. B.; Schlegel, G. E.; Robb, M. A.;
Cheeseman, J. R.; Scalmani, G.; Barone, V.; Mennucci, B.; Petersson, G. A.; Nakatsuji, H.; Caricato, M.; Li, X.; Hratchian, H. P.; Izmaylov, A. F.; Bloino, J.; Zheng, G.; Sonnenberg, J. L.; Hada, M.; Ehara, M.; Toyota, K.; Fukuda, R.; Hasegawa, J.; Ishida, M.; Nakajima, T.; Honda, Y.; Kitao, O.; Nakai, H.; Vreven, T.; Montgomery Jr., J. A.; Peralta, J. E.; Ogliaro, F.; Bearpark, M. J.; Heyd, J.; Brothers, E. N.; Kudin, K. N.; Staroverov, V. N.; Kobayashi, R.; Normand, J.; Raghavachari, K.; Rendell, A. P.; Burant, J. C.; Iyengar, S. S.; Tomasi, J.; Klene, M.; Knox, J. E.; Cross, J. B.; Bakken, V.; Adamo, C.; Jaramillo, J.; Gomperts, R.; Stratmann, R. E.; Yazyev, O.; Austin, A. J.; Cammi, R.; Pomelli, C.; Ochterski, J. W.; Martin, R. L.; Morokuma, K.; Zakrzewski, V. G.; Voth, G. A.; Salvador, P.; Dannenberg, J. J.; Dapprich, S.; Daniels, A. D.; Farkas, Ö.; Foresman, J. B.; Ortiz, J. V.; Cioslowski, J.; Fox, D. J.; Cossi, M.; Rega, N.; Millam, N.; Gaussian 09, version D.01; Gaussian, Inc.: Wallingford, CT, USA, 2009.

24. Dennington, R.; Keith, T.; Millam, J.; Gauss View, version 5.0.8; Semichem. Inc.: Shawnee Mission, KS, 2008.

25. Grimme, S.; Antony, J.; Ehrlich, S.; Krieg, H.; J. Chem. Phys. 2010, 132, 154104.

26. Tomasi, J.; Mennucci, B.; Cancès, E.; J. Mol. Struct.: THEOCHEM 1999, 464, 211.

27. Bader, R. F.; Atoms in Molecules A Quantum Theory; Oxford University Press: Oxford, UK, 1999.

28. Wolinski, K.; Hinton, J. F.; Pulay, P.; J. Am. Chem. Soc. 1990, 112,8251 .

29. Benassi, E.; J. Comput. Chem. 2017, 38, 87.

30. Pierens, G. K.; Venkatachalam, T. K.; Reutens, D. C.; Sci. Rep. 2017, 7, 5605.

31. Pierens, G. K.; J. Comput. Chem. 2014, 35, 1388.

32. Nascimento, P. F. C.; Nascimento, A. C.; Rodrigues, C. S.; Antoniolli, A. R.; Santos, M. P. O.; Júnior, A. M. B.; Trindade, R. C.; Rev. Bras. Farmacogn. 2007, 17, 108.

33. Pereira, F. O.; Mendes, J. M.; Lima, I. O.; Mota, K. S. L.; Oliveira, W. A.; Lima, E. O.; Pharm. Biol. 2015, 53, 228.

34. National Committee for Clinical and Laboratory Standards (NCCLS); Performance Standards for Antimicrobial Disk Susceptibility Tests, $7^{\text {th }}$ ed.; NCCLS: Villanova, 2000.

35. Hadacek, F.; Greger, H.; Phytochem. Anal. 2000, 11, 137.

36. Cleeland, R.; Squires, E. In Evaluation of New Antimicrobials in vitro and in Experimental Animal Infections; Lorian, V., ed.; Antibiotics in Laboratory Medicine, Lippincott Williams \& Wilkins: Baltimore, 1991, p. 739.

37. Espinel-Ingroff, A.; Chaturvedi, V.; Fothergill, A.; Rinaldi, M. G.; J. Clin. Microbiol. 2002, 40, 3776.

38. Tormena, C. F.; Prog. Nucl. Magn. Reson. Spectrosc. 2016, 96 , 73.

39. Mary, Y. S.; Raju, K.; Panicker, C. Y.; Al-Saadi, A. A.; Thiemann, T.; Spectrochim. Acta, Part A 2014, 131, 471.

40. Sjoberg, P.; Politzer, P.; J. Phys. Chem. 1990, 94, 3959. 
41. Fleming, I.; Molecular Orbitals and Organic Chemical Reactions; John Wiley \& Sons Ltd.: Cambridge, UK, 2010.

42. Parr, R. G.; Szentpály, L. V.; Liu, S.; J. Am. Chem. Soc. 1999, 121, 1922.

43. Domingo, L. R.; Ríos-Gutiérrez, M.; Pérez, P.; Molecules 2016, 21, 784 .
44. Lodewyk, M. W.; Siebert, M. R.; Tantillo, D. J.; Chem. Rev. 2012, 112, 1839.

45. Siddiqui, Z. N.; Farooq, F.; Musthafa, T. N. M.; Ahmad, A.; Khan, A. U.; J. Saudi Chem. Soc. 2013, 17, 237.

Submitted: July 23, 2020

Published online: October 9, 2020 